\title{
"Freshest advices"?: The currency of London news in Dublin City newspapers, 1790 - 1801
}

\author{
Sarah McDonald
}

\begin{abstract}
This paper summarises a MLIS dissertation which studied the currency of news, sourced from London newspapers and re-printed in Dublin City newspapers, during the final decade of the eighteenth century. London was a vital communications network hub for the dissemination of information, consisting of British and Foreign Intelligence, to Irish port cities such as Dublin. Using the resources of recently digitised London and Dublin newspaper series, it was possible to build a model which accurately represents the transmission time for London 'News' into Dublin editorial offices. The model provides a frequency distribution from which the minimum, maximum and average transmission times are established. It is argued that the same method can reliably be applied to determine the transmission time for news from the main European cities to London and Dublin.
\end{abstract}

\section{Introduction}

During the eighteenth-century, London and Paris were gateways to wider cultural and intellectual horizons for the Irish citizen. These European capitals, among others, acted as hubs in the transmission of mainstream current affairs and 'News' reporting to Dublin and other Irish port towns. News which was printed in the London press was transported by British postal service and packet ships across the Irish Sea to Dublin. Relying heavily on the content of the London newspapers for copy, Dublin printers composed, printed and distributed their newspapers to street hawkers, booksellers, coffee-houses and circulating libraries. The idea of news currency and therefore the value of the news product changed in terms of people's expectations as the decades passed. The life-cycle of 'News' as a product determined how up-to-date news was with regard to contemporary perception. But just how was Dublin's current awareness of events elsewhere affected, and

\section{Sarah McDonald}

Sarah McDonald graduated from University College Dublin in 2010 with a Master of Library and Information Studies. Previously, she was Head of Information Systems in the private sector.

Email: sarahmcdonaldmlis@gmail.com 
impeded even, by the country's physical geographic position; in effect an island beyond an island off the Continental mainland? Negotiating the often treacherous conditions in Dublin Bay, Waterford Harbour, or at the Port of Donaghadee was a continual physical barrier to the arrival of the latest newspapers mailed from London.

\section{Dublin's print trade and packet ships}

The population of the city of Dublin rose to 182,000 by the end of the eighteenthcentury yet "we do not know how many English speakers would read, nor indeed, how many Irish speakers could understand English, let alone read it" (Pollard, 1989, 211-2). At the time of the Union in 1800, Ireland probably held a population of two million Irish-speakers, one-and-a-half million Irish-English bilinguals, and one-and-a-half million English-speakers (Bew, 2007, 62-3). Certainly, Ireland's level of illiteracy, compounded by the need to cater for two languages and two major religions, created substantial challenges for the Irish print trade. It was an era of heavy taxation and threat of prosecution for seditious libel; survival, rather than profit, became the key issue for most print houses. The decision was easily made. "The Dublin book trade catered first and foremost for the English-speaking Protestant ascendancy. The needs of the Catholic majority were served slowly and sparingly" (Pollard, 1989, 225).

The print trade in Dublin reached its peak in membership in the early 1790s but by the end of the decade there was a noticeable decline, probably caused by the effects on trade of the war with France; traditional French sources were cut off by war, and supplies from England and Scotland attracted heavy import duties (Kinane, 2002, 20). In addition, the Press Act of 1798 meant that only newspapers which were organs of Dublin Castle or had a well-established income from advertising could survive the increase in taxes, penalties and sureties (Inglis, 1954, 109-10). This was an era of unprecedented political and cultural change for Ireland yet the channels for influencing and communicating those changes were increasingly muzzled and potentially biased.

The heart of the old city of Dublin was also the heart of its print trade.

From 1750 to 1810, Dublin was dominated by a strong merchant and trading community ... [centred on] the Temple Bar district [and] dominated by the Old Custom House on the quays and the Exchange House on Cork Hill.

(Cox, 2000, 31-2)

The location of the print trade so close to the Custom House and quays was not unintentional. The time of going to press depended entirely upon the arrival, by packet ship, of the 'Mail' containing the London news, and the schedule of postal service out of Dublin to other parts of Ireland. Gandon's new Custom House at Custom House Quay opened for business in November 1791 "with a wharf in front and a road to the packet station skirting the chief entrance" (Marmion, 1860, 230-1). It replaced the dilapidated old Custom House on Essex Quay which was built in 1707 and with this move the progressive development of the city eastwards was hastened. The growth in trade and traffic necessitated the construction of a new bridge in 1794 over the river Liffey, Carlisle Bridge, also by 
Gandon, and later rebuilt as O'Connell Bridge. As this was the east-most bridge on the Liffey it had the effect of cutting off a stretch of river previously used to berth sailing ships and discharge their cargoes with the result that only rowing boats could now pass upstream under Carlisle Bridge to the old heart of Dublin city (Gilligan, 1988, 97). The importance of the Dublin coffee-house in the dissemination of information is significant. In both Dublin and London most coffee-houses found it necessary to offer a selection of newspapers for their customers. This facility met the needs of "those who could not or would not pay the full price of the newspaper" but were instead able to read for free - or by subscription ${ }^{1}$ - in the coffee-house, "hire copies from a hawker ... or club together to buy a copy". Thus readership of newspapers was "more widespread than circulation figures alone suggest" (Boyce et al, 1978, 91).

Prior to the advent of railways and steam-ships, communications between Ireland, Great Britain and the Continent were entirely dependent on favourable weather, tides, working conditions, and roads. London newspapers travelled by scheduled British postal service mail-coach, or 'By Express' horse and rider, to Holyhead. In England, Scotland and Ireland the development of the newspaper industry was "intimately linked to the improvement of roads [and] the growing efficiency of the General Post Office" (Boyce et al, 1978, 89). Despite the introduction of mail stage-coaches by Palmer in Britain in 1784, travelling speed remained at four to five miles per hour - the maximum speed at which a team of horses could be expected to pull a mail coach over common roads a set distance of up to twenty miles before a fresh team was required (Willson, 1903, 24). ${ }^{2}$ It regularly took eighty-two hours to travel 400 miles between London and Edinburgh - equating to a speed of less than five miles per hour. ${ }^{3}$ One hundred and eighty years earlier the situation was very similar. When Queen Elizabeth I died at 3am on Thursday, 24 March 1602, the Council met at Whitehall and by 10am had proclaimed James VI of Scotland as the new King of England. Sir Robert Cary rode at 'express' speed to Edinburgh covering 400 miles in three days to bring the news to the new King:

Consequently, lowland Scotland, or at least Edinburgh, may have learned of the change of dynasty before some parts of England. It took considerably longer for the news to travel to rebellion-torn Ireland; the earl of Tyrone, his armies worn out and his supplies exhausted, surrendered to the late queen on 3 April, still in ignorance of her death.

${ }^{1}$ At Hyde's coffee-house in Dublin, subscribers paid a guinea's subscription a year to retire to a specially reserved apartment to read the newspapers and debate their contents (Oram, 1983, 36).

${ }^{2}$ In 1798 the Holyhead mail left London at eight at night and arrived in Shrewsbury between ten and eleven the following night, taking twenty-seven hours to run 162 miles [6mph] (Willson, $1903,19,25)$. In 1828, with the benefit of better roads, the coaches travelled from London to Holyhead, a distance of 261 miles, in twenty-nine hours [9mph] (Hemmeon, 1912, 105).

${ }^{3}$ It would not be until 1816 that Telford and Macadam paved the way, literally, for more rapid transit by creating a level road surface that enabled one horse to pull what it would take four horses to do on an unpaved road. With this invention, the Edinburgh to London mail ran 400 miles in forty hours, stoppages included, which was at the rate of nearly eleven miles an hour. The maximum speed obtainable by the mail-coach on a good road had been reached (Willson, 1903, 26). 
(Woolf, 2001, 84-5).

This clearly highlights how distant, in communication terms, various parts of the kingdom were from London, and how that remoteness created multiple, and sometimes conflicting, versions of reality for the people.

In the eighteenth century three routes, known as the 'Domestic Packets' were used for mail crossing the Irish Sea: Donaghadee to Port Patrick (22 miles), Holyhead to [Dublin (60 miles)] and Milford Haven to Waterford or Dunmore (about 80 miles). Although the boats were not large, usually less than 100 tons and manned only by ten men, they kept the schedule as closely as tide and weather would allow. The final hour for posting letters changed daily according to the tides.

(Reynolds, 1983, 48)

The principal route across the Irish Sea was Dublin to Holyhead.

Surveys [prior to 1829] proved that it took an average 20 hours to go from Holyhead to the Pigeon House [Dublin], 17 hours from the Pigeon House to Holyhead.

(Reynolds, 1983, 49)

Adverse weather and unfavourable tides played havoc with the packet schedule. The prevailing westerly winds meant that delays on the Holyhead to Dublin route were more frequent than on the reverse route. The route was served by five packet boats on a daily service. The extensive sandbar (Dublin Bar) running north-south in Dublin Bay effectively formed a barrier to shipping at the entrance to the River Liffey except at high water. The packet boats had to lie off-shore until there was sufficient water to cross the Bar. When Sir George Shee wrote 'A Memoir on the Construction of Ships' to be read at the Royal Irish Academy, 1 November 1794, he specifically highlighted the difficulties which the Dublin Bar created for packet ships:

The construction of vessels employed in carrying mails between Dublin and Holyhead ... can float on the Dublin Bar only at a particular time of tide, by which fair winds are frequently missed, and passage from England unnecessarily prolonged. From their want of length and excessive depth they are such slow sailers, that the Favourite, a light long vessel ... has made her passage to Holyhead in nine hours, when two packets, which weighed anchor when she did, took twelve to perform theirs.

(Shee, 1797, 24)

The Admiralty Hydrographic Service was established in 1795 but it was not until 1800 that the Board of Admiralty directed that a survey of Dublin Bay be taken by Captain William Bligh ${ }^{4}$ of the Royal Navy. Prior to this, mariners used

\footnotetext{
${ }^{4}$ Bligh recommended that the North Bull Wall be constructed parallel to the South Bull Wall to prevent sand building up in the mouth of the harbour. It was not until the completion of the North Bull Wall in 1842 that Bligh's forecasted natural scouring action of the Liffey estuary began and sand was deposited outside the shipping channel to create Bull Island, thus enabling shipping to pass over the Bar at any time (Dublin Docklands, 2009, History and Heritage at http://www.ddda.ie ).
} 
'unofficial' maps of Dublin Bay showing hydrographic information as the depth of the water in feet at low tide.

In 1796, the Post Office decided to maintain small vessels of about forty tons, known as wherries, at Holyhead and Dublin [in the event that] conditions were against packets trying to enter the Liffey [...] the mails could be transferred to wherries in Dublin Bay to be taken ashore.

(Gilligan, 1988, 104)

Normally, passengers and mail disembarked at the Custom House. The reconstruction of the South Bull Wall in the 1750s provided alternative disembarkation points at Ringsend and the Pigeon House when packets were unable to progress up the river.

It seems likely that reciprocal agreements were in place between certain Dublin and London newspaper printers whereby they exchanged copy. Content from the London Gazette appears regularly, word for word, in the Freeman's Journal and other Dublin newspapers. On arrival at the Dublin printer, the London papers had to be reviewed and content selected for inclusion in the issue of the Dublin paper undergoing composition, or even those already on the press. Late arrival of the London papers meant the press had to be stopped and the newest content added to the chase of set type for printing. The Freeman's Journal on 25 June 1796 stated "We stop the press to state that a mail has just arrived, which brings a London Gazette containing important intelligence ... which we shall give in a Postscript Extraordinary". Carr describes the Dublin street newspaper hawker thus:

Opposite to the grand front of the late parliament-house is the general post-office, where the ear is annoyed with newsmen, crying out, "Two packets, two packets" meaning that the news, which they hold in their hands, contain the intelligence brought by that number of packets last arrived from England.

(Carr, 1806, 52)

Working conditions and time pressures for the Dublin newspaper printer were similar to those in London. "The later a newspaper could be sent to press, the better the chance of including late despatches or parliamentary reports" - this affected the composing department and the press room (Howe, 1947, 372). However, daily newspapers imposed extra demands: "The Full Hands on daily newspapers were compositors engaged to attend the office for ... twelve [hours]" (Howe, 1947, 373). These working hours necessitated composition by candlelight for a large portion of the year. It is evident from the Freeman's Journal that late night composition was a regular activity: “At twelve o'clock last night arrived four mails", Dublin pressmen were paid by the hour in accordance with the number of impressions required (Pollard, 1989, 125-6; Wiles, 1965, 91). "With two men at the press, one to ink and the other to pull the forme, a production rate of 250 sheets per hour, printed on one side, was expected" (Howe, 1947, 95). Language translation of foreign intelligence is not apparent in the Freeman's Journal so it seems likely that the newspaper relied on translations already made for the London papers. Delays caused by translation would therefore have been

${ }^{5}$ Freeman's Journal, 5 Jan. 1796. 
incurred at the London link of the chain. In London, "Postal clerks had a monopoly in the translation of foreign-language papers and reports for which a fee was charged. This also held up delivery" (Williams, 1977, 39). The Times was particularly noted for its coverage of foreign news having established Foreign Correspondents at Brussels and Paris in 1792. ${ }^{6}$

\section{The time value of the news}

The history of the spread of information has repercussions on "our knowledge of the history of everyday life, the history of commodities and the history of mentalities". "Information helped form a modern conception of time" (Dooley and Baron, 2001, 8). But the concepts of 'Time', 'Currency' and 'The Present' are hard to define. In terms of 'News' in the pre-industrial revolution era these concepts are relative:

From the point of view of a person receiving news of a great event, and recording it or passing it on to an acquaintance, there was an unbridgeable temporal gap between the event itself and his or her perception of it ... Our perception of news is very different from that of [eighteenth century people], because both our technology and our relationship to that technology is radically different; theirs, in turn, differed from that of the pre-print era.

(Woolf, 2001, 83)

News has a time value - it has to be 'current' to be valuable (Komito, 2004, 25). Depending on logistical and geographical factors, 'currency' had different meanings for different demographic concentrations. Similarly, for some, 'News' was a source of important intelligence, while for others it was merely a source of diversion. The more news ages, the more likely it is to be read for entertainment rather than intelligence. As long as news was current, it did not lose its value. As well as having a value, news also had a price. Apart from the cost of the newspaper, acquiring literacy skills required an investment. "Many people were therefore not literate, because it was not seen as worth the investment". Literacy was a powerful tool which "would be at the very least a waste, and at the worst dangerous, in the hands of peasants". Restricting literacy made people dependent on others and resulted in "differential access to information" (Komito, 2004, 22).

The second half of the eighteenth century was a period of great political revolution in America and Europe, and this demanded an unprecedented attention to the creation and dissemination of information in the form of news and comment. The same was true for Ireland and Great Britain in the lead-up to the Union. The Dublin press recognised that the communications network was centred in London and that "it was easier and cheaper to reprint accounts from the English press than to employ reporters" (Inglis, 1954, 229). "The format which began in the metropolitan centre of London was imitated by the principal print centres of the empire in an effort to recreate exactly the success of the original template" (Archbold, 2008, 270). To the same end, the Dublin newspaper printer also imitated the format of the London newspaper and copied its content.

${ }^{6}$ Times, 21 May 1792. 
The spread of newspapers from one country to another was itself a network phenomenon: much of the content of individual papers consisted of news items taken from other papers, thanks to the emerging international postal network. If we think of the newspapers themselves as forming a communications network, the more 'nodes' transmitting information, the more any individual paper could offer at little extra cost to itself.

(Starr, 2005, 33)

Expanding markets increased the appetite for information about the wider world. In the Freeman's Journal for this period the space devoted to British and Foreign Intelligence generally exceeded that given to domestic news. For the Dublin newspapers, there was an inherent delay by having to wait for the arrival of newspapers from London, yet without access to the news those papers contained, Dublin's awareness of international events would have been severely crippled. For researchers of eighteenth-century Ireland, the speed at which Dublin learned of remote events - via the communications hub which was London - can be a crucial piece of information.

\section{Methodology}

This historical research was based on a combination of instrumental and collective case studies of London news reporting in Dublin papers and primarily involved document analysis and experimental dataset construction. In the absence of meteorological records for the eighteenth-century ${ }^{7}$ it is not possible to model the weather conditions which prevailed at particular seasons and dates for the arrival of mail and packet ships trying to enter Dublin Bay. However, using the resources of recently digitised London and Dublin newspaper series, it is possible to build a model which accurately represents the transmission time for London 'News' into Dublin editorial offices. We will see that the same method can reliably be applied to determine the transmission time for news from the main European cities to London and Dublin.

For this study, all 1,638 available issues in the digitised surrogate ${ }^{8}$ of a Dublin newspaper, the Freeman's Journal, 1790 to 1801 inclusive, were examined to create a dataset and model containing the transmission time for all the London news reported in the Freeman's Journal. In addition, to verify the findings, a sample of twenty specific events were tracked in two London newspapers followed by five Dublin newspapers to determine the transmission time for the reporting of each of those events and compare the results with those of the Freeman's Journal model. The focus was on the particularly turbulent years of the 1790s, with the start of the French Revolutionary wars. Dublin (and London) newspapers of the time reported British and Foreign Intelligence in column

\footnotetext{
${ }^{7}$ Richard Kirwan's 'Meteorological Observations' from 1790 to 1799 were examined but these did not contain sufficient level of detail for weather modelling. Meteorological observations were taken at the Royal Botanical Gardens in Glasnevin from 1800 and published yearly in the Proceedings of The Royal Dublin Society but it was not until 1860 that 'operational meteorology' began in Ireland (Met Eireann, 2009).

${ }^{8}$ Irish Newspaper Archive available at http://www.irishnewsarchive.com.
} 
paragraphs headed with the city of origin and the date of the mail(s) from which their reports are taken (see Figure 1).

Since our lajt arrived Two Britije Mails,
LONDON, DEC. I, 2.

Figure 1: Examples of dated paragraph headers from the Freeman's Journal.

These dated paragraph headers are key to the calculation of the transmission time; namely, the difference between the publication date ${ }^{9}$ of the Freeman's Journal and the date of the mail containing the London news. The dated paragraph headers were found to be an accurate and reliable indicator of the transmission time for the re-printing of London news. The London mails were always reported in sequence and there were few gaps in the sequence. To test the validity of the dates given in the Freeman's Journal, a selection was cross-checked against the corresponding dates in the London papers. With the validity verified, the dates were used to create a model of the transmission time for reporting London news in the Freeman's Journal. A summary of the model is given in Table 1 and graphically in Figure 2.

\begin{tabular}{|c|c|c|c|c|c|c|c|c|c|c|c|c|c|}
\hline $\begin{array}{c}\text { T-Time in } \\
\text { Days }\end{array}$ & 3 & 4 & 5 & 6 & 7 & 8 & 9 & 10 & 11 & 12 & 13 & 14 & 15 \\
\hline $\begin{array}{c}\text { Frequency } \\
1790-1801\end{array}$ & 17 & 558 & 1339 & 830 & 487 & 164 & 39 & 30 & 13 & 7 & 1 & 1 & 1 \\
\hline $\begin{array}{c}\text { Mean T-Time } \\
\text { in days }\end{array}$ & \multicolumn{10}{c|}{5.621} \\
\hline $\begin{array}{c}\text { Standard } \\
\text { Deviation }\end{array}$ & \multicolumn{10}{c|}{1.31} \\
\hline
\end{tabular}

Table 1: Frequency distribution, mean and standard deviation of the transmission time (T-Time) in days for reporting news from 3,487 London mails in 1,638 issues of the Freeman's Journal, 1790-1801.

Table 1 shows that, over a twelve-year period, the shortest transmission time for re-printing a London newspaper article in a Dublin newspaper was three days. This happened only seventeen times in 3,487 London mails. The mean transmission time for the period was 5.621 days. The longest transmission time was fifteen days ${ }^{10}$. For the Dublin reader, the London news was generally

\footnotetext{
${ }^{9}$ From [at least] January 1790 until the end of May, 1793, the banner of the Freeman's Journal stated the issue date in the form "From Tuesday, May the 28th, to Thursday, May the 30th, 1793". The publication date for these issues is the second of the two dates; in this case Thursday, 30 May 1793.

${ }^{10}$ A single period of stormy weather preceeding 18 Jan. 1791 accounted for all the delays shown of 13, 14 and 15 days; the Freeman's Journal of 18 Jan. reported the arrival of 10 mails, 9 of which arrived on a single day. Weather reports were regularly provided to readers to account for the packet delays.
} 
available four to seven days later than for its London reader, as indicated by the low standard deviation of just 1.31 days.

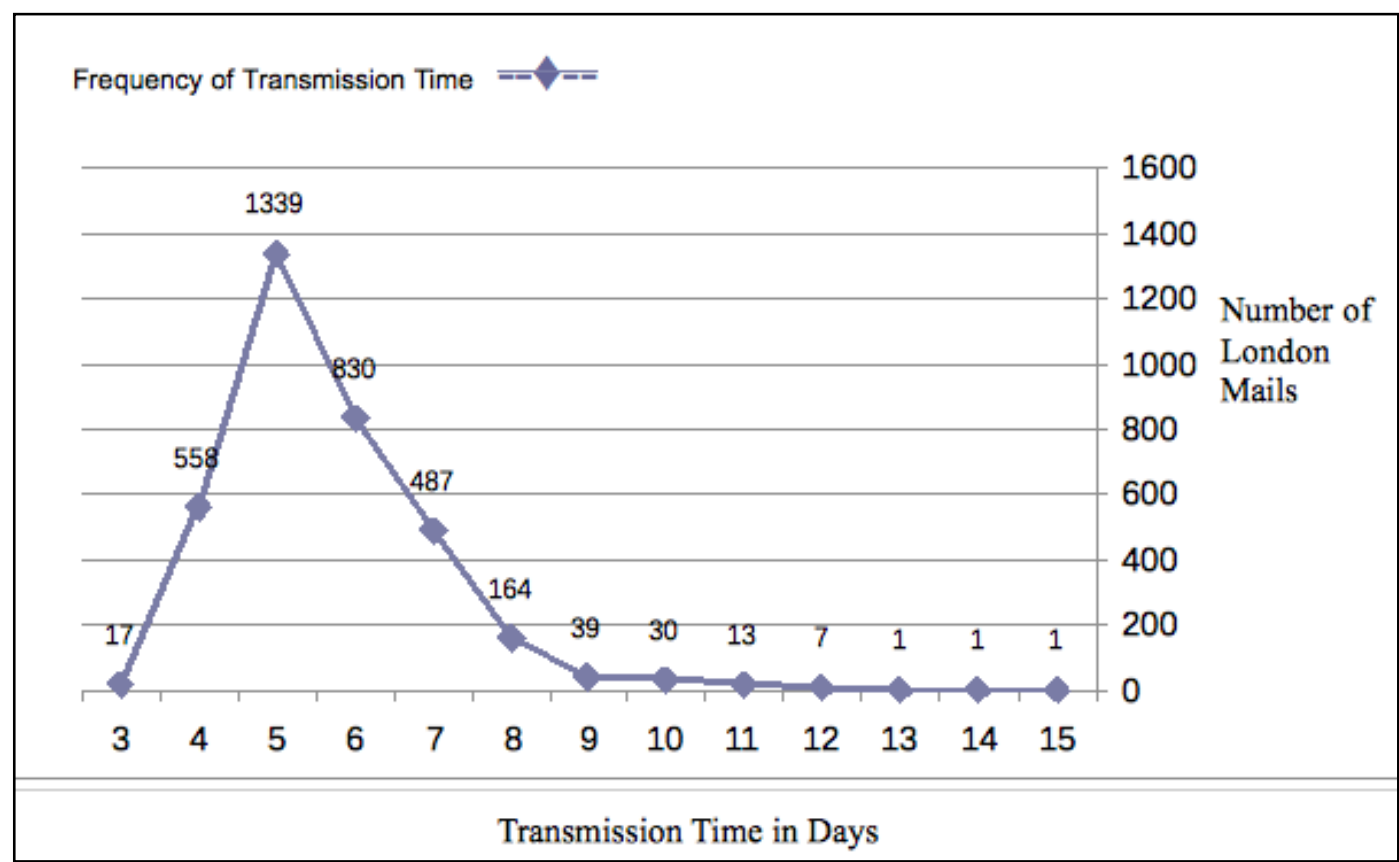

Figure 2: Frequency distribution of the transmission time for reporting news from 3,487 London mails in the Freeman's Journal, 1790-1801.

\begin{tabular}{|c|c|c|c|c|c|c|c|c|c|c|c|c|}
\hline Year & Jan & Feb & Mar & Apr & May & Jun & Jul & Aug & Sep & Oct & Nov & Dec \\
\hline $\mathbf{1 7 9 0}$ & 5.96 & 6.20 & 5.95 & 5.89 & 5.48 & 6.00 & 5.74 & 5.93 & 6.29 & 5.85 & 5.77 & 7.56 \\
\hline $\mathbf{1 7 9 1}$ & 7.88 & 6.78 & 5.45 & 5.12 & 5.37 & 5.12 & 5.28 & 5.54 & 5.70 & 6.03 & 6.22 & 7.48 \\
\hline $\mathbf{1 7 9 2}$ & 5.59 & 5.57 & 6.14 & 5.81 & 5.37 & 5.17 & 5.07 & 5.59 & 5.88 & 6.11 & 5.69 & 7.48 \\
\hline $\mathbf{1 7 9 3}$ & 5.75 & 6.55 & 5.96 & 5.26 & 5.26 & 5.61 & 5.17 & 5.64 & 5.46 & 5.59 & 5.58 & 5.62 \\
\hline $\mathbf{1 7 9 4}$ & 5.65 & 7.07 & 6.06 & 5.00 & 5.19 & 5.19 & 5.03 & 4.74 & 5.72 & 6.48 & 5.13 & 6.41 \\
\hline $\mathbf{1 7 9 5}$ & 5.56 & 6.11 & 5.96 & 5.00 & 5.16 & 5.23 & 5.36 & 5.35 & 5.26 & 5.72 & 6.54 & 6.69 \\
\hline $\mathbf{1 7 9 6}$ & 7.10 & 6.37 & 5.71 & 5.08 & 5.50 & 5.57 & 5.06 & 5.26 & 5.09 & 5.91 & & \\
\hline $\mathbf{1 7 9 7}$ & & & 5.18 & 5.13 & 5.30 & 5.23 & 5.04 & 5.35 & 5.44 & 5.42 & 5.55 & 5.75 \\
\hline $\mathbf{1 7 9 8}$ & 5.75 & 5.75 & 5.38 & 5.10 & 5.29 & 5.30 & 5.48 & 5.24 & 5.57 & 5.44 & 5.58 & 5.63 \\
\hline $\mathbf{1 7 9 9}$ & 5.21 & 7.12 & 5.29 & 5.33 & 5.00 & 5.60 & 7.68 & 5.24 & 5.11 & 5.45 & 6.09 & 5.20 \\
\hline $\mathbf{1 8 0 0}$ & 5.42 & 4.50 & 4.88 & 5.26 & 5.14 & 5.27 & 5.32 & 5.13 & 5.18 & 5.70 & 5.70 & 5.23 \\
\hline $\mathbf{1 8 0 1}$ & 5.66 & 5.41 & 5.08 & 4.77 & 5.03 & 5.06 & 5.03 & 4.93 & 4.96 & 5.06 & 5.33 & 5.57 \\
\hline Avg. & $\mathbf{5 . 9 6}$ & $\mathbf{6 . 1 3}$ & $\mathbf{5 . 5 9}$ & $\mathbf{5 . 2 3}$ & $\mathbf{5 . 2 6}$ & $\mathbf{5 . 3 6}$ & $\mathbf{5 . 4 4}$ & $\mathbf{5 . 3 3}$ & $\mathbf{5 . 4 7}$ & $\mathbf{5 . 7 3}$ & $\mathbf{5 . 7 4}$ & $\mathbf{6 . 2 4}$ \\
\hline
\end{tabular}

Table 2: Average transmission time in days for London news printed in the Freeman's Journal, 1790-1801, per month, per year. (Issues for Nov./Dec. 1796 and Jan./Feb. 1797 were missing from the digitised archive.) 
Not surprisingly, the detailed data shows that the Winter months display a volatility that is not evident in the Summer months (see Table 2). The months April to September show the least volatility and therefore the optimum window of predictability regarding the expected transmission time for receiving London mails. There is also evidence of a weak, yet visible, downward trend over the twelve-year period (see Table 3). Improvements in the chain of transmission may have contributed to this modest (almost one day) reduction in the average transmission time. There is no evidence that the construction of Carlisle Bridge (now O'Connell bridge) or the relocation of the Custom House had a negative impact on the transmission time.

\begin{tabular}{|l|l|l|l|l|l|l|l|l|l|l|l|l|}
\hline Year & 1790 & 1791 & 1792 & 1793 & 1794 & 1795 & 1796 & 1797 & 1798 & 1799 & 1800 & 1801 \\
\hline $\begin{array}{l}\text { Avg. } \\
\text { T-Time }\end{array}$ & 6.06 & 6.06 & 5.79 & 5.60 & 5.67 & 5.69 & 5.75 & 5.35 & 5.46 & 5.44 & 5.28 & 5.16 \\
\hline
\end{tabular}

Table 3: Average transmission time in days for London news printed in the Freeman's Journal, 1790-1801, per year.

The periodicity of the Freeman's Journal - a tri-weekly, printed on Tuesday, Thursday and Saturday - was just as significant, if not more so, as a factor affecting the currency of the news than the arrival of the packet ship. If a mail arrived after the publication of Saturday's paper then it would have an imposed time-lag of an extra three days - until the following Tuesday's issue - in addition to the 'natural' lag incurred due to regular logistical and environmental factors. Proceedings of the British and Irish parliaments were regularly reported in the newspapers when the Houses were in session (Nov./Dec. to June/July). London papers reported the proceedings promptly - usually the following day or in the next issue - thus the typical transmission time for British parliamentary proceedings being reported in the Dublin press was the standard transmission time plus one day.

Usage of mails from Donaghadee <> Port Patrick and Waterford $<>$ Milford Haven routes was explicitly mentioned when bad weather closed the Holyhead route. Donaghadee mails were used for eleven issues and Waterford mails for four issues. This contingency would have added two or more days to the overall transmission time.

Newspapers were not published with 'early' or 'late' editions, but the content of the final copy of an issue was likely to be different from an earlier copy if a British mail arrived before printing was completed ${ }^{11}$. This newest content was often included as a 'Postscript Extraordinary' on the final page printed; this was not necessarily the last page in the newspaper. In the case of the Freeman's Journal (a 4-page, two-sided sheet), late news and Postscript Extraordinary generally appeared on page four but also appeared on page one (usually in the rightmost column). There is also evidence that full copies were printed a little

11 "We stop the press to insert the particulars of the Mail arrived at eight o'clock this morning" (Freeman's Journal, 11 May 1799). 
earlier for distribution outside Dublin than the final copies intended for the Dublin consumer. In the Freeman's Journal, 17 December, 1795, it is stated "The following Gazette having but appeared in our country number of Tuesday, we repeat it, as our duty for our town readers". A consequence of this practice is that the earlier 'country edition' might contain different news from that of the 'city edition', or might not contain the latest news from abroad. Any such missing news was not repeated in the next published issue so it is unclear how it was disseminated to the non-Dublin readership, if at all. Final composition was usually completed by noon on publishing day. A small number (51) of issues contained news items with the heading 'By Express'. The data shows that the news contained in these paragraphs was no more current than the regular London mails which travelled by the normal mail-coach service from London to Holyhead, rather than by Express rider. This suggests that the sea-crossing / Dublin Bay was the critical bottleneck in the chain of transmission from London to Dublin.

\section{Conclusion}

Insufficient primary source data exists with which to build a robust model of the environmental and logistical factors on which the chain of transmission of news from London to Dublin depended during the period 1790-1801. In particular, the absence of a comprehensive set of meteorological records meant that the history of a critical factor, the weather, could not be modelled for this research.

Nevertheless, the Freeman's Journal provided a source of recurrent, consistent and reliable data with which to build a model of the transmission time for the reporting of London - and by extension, other foreign cities - news in Dublin. Results demonstrate clearly that the physical transmission time for news into Dublin editorial offices, was on average, just under a week; $5.3-5.7$ days. Very rarely was news in transit for less than four days. What was 'News' for a Dublin reader, therefore, were the European concerns of a week ago for the London reader. Ireland's harbour cities, as benchmarks for what was 'current' and what was obsolete information, appear to have diverged markedly from their inland counterparts, with their readers sharing many more of the horizons and concerns of port communities elsewhere, rather than those of the inland counties.

Indicators from this research also demonstrate what would be required for the full modelling for the physical arrival of 'Foreign Intelligence' from the Continent.

\section{Implications for LIS practitioners}

\subsection{Transferability of findings}

This study suggests that the transferability of the methodology or approach for other port cities/geographical area or other categories of imported news is possible. However, the transferability of findings does not apply to other types of printed information such as books or pamphlets; these items were printed for a different purpose and to a different timescale than newspapers. For example, a pamphlet on the Act of Union was a reflective work generally printed some time after the events it discussed and without the urgency required for a newspaper 
report $^{12}$. The transmission times reported in Table 2 apply to London news which, by its very nature, was prioritised for reprinting by the Dublin press. Reprinting of other works sourced from London would not follow this frequency distribution.

\subsection{Virtual Research Environments}

Digitised surrogates of primary sources offer advantages, such as search and browse facilities, over microfilm and the original but the researcher needs to show a critical detachment from the surrogate. Errors can be introduced during the digitisation process. During the Freeman's Journal case study, 461 (7\%) pages with dated paragraph headers were found to be mis-filed in the digitised surrogate. It was possible to 'logically' re-file these pages in their correct issues of the newspaper during the data capture. As a result, the data from those pages was not omitted from the case-study. Many more pages which did not have dated paragraphs were also identified as being mis-filed but were not of interest to this study. It was not possible to logically relocate some of these pages.

Up until the end of May, 1793, the banner of the Freeman's Journal stated the issue date in the form "From Tuesday, May the $28^{\text {th }}$, to Thursday, May the $30^{\text {th }}$, 1793". The publication date is the second of the two dates, yet in the surrogate the issue is 'incorrectly' filed under the first date.

There were a number of instances where the first page of an issue of the Freeman's Journal was missing from the surrogate so it appeared as if the whole issue was missing because issues are indexed for retrieval based on the existence of page one. As a consequence, the 'orphaned' pages two, three and four were mis-filed as a continuation of the previous issue.

A balance needs to be found between the convenience of a digitised collection and the quality assurance provided by study of the originals. The importance of maintaining a critical detachment from a digital surrogate was proven beyond doubt; the convenience of desktop-based research and reliance on virtual research environments can lead researchers, unwittingly, into error. Wusteman (2008) proposes that librarians take a proactive role in the development, training and use of virtual research environments. A finding of this study suggests an additional role for librarians, namely, providing a valuable service to researchers by validating the digital surrogates in their collections.

\subsection{Newspapers and society}

Sommerville $(1996,4)$ stated how news created "a new kind of reading public, even a new society". The newspapers encouraged this perception of their status and value to society; “... this undeniable truth - that the Freeman's Journal finds its way into the circles of rank and fashion, and is read by every family of distinction in Ireland and Great Britain." (Freeman's Journal, 19 October 1790,

\footnotetext{
${ }^{12}$ In the Freeman's Journal, 7 February, 1799, J. Moore advertised his publication of a summary report of the Union debates in the Irish House of Commons from the 22 and 24 January. In the Freeman's Journal of 16 February, 1799, John Exshaw advertised his publication of Pitt's speech on the Union in the British House of Commons from the 31 January, to which he added related speeches from August 1785.
} 
4). Barnard $(2006,51)$ says "the expectation was that a man of [good] standing ... might reasonably be assumed to read the papers", indicating the necessity of being well-informed. The similarity of content and style, and the promotion of London intelligence among the five Dublin newspapers in this study supports Barnard's suggestion that "these features may have strengthened the sense in some readers of belonging to a Britannic or Anglophone community not confined to Ireland" (Barnard, 2006, 51). The passing of the Act of Union and many other mechanics of the Anglicisation of Ireland were well-oiled directly and indirectly by the Dublin press.

Not only was the content of the news of interest, but the timing of its arrival by packet ship in Dublin was a recurring event that caused (a) the urban dweller to consider if, and when, he should look for news, and (b) the newspaper printer to decide what news would be disseminated - and when. The deliberation on these decisions was more acute in the era of tri-weekly newspapers and an unpredictable environment. People's information-seeking and informationprocessing behaviour may well have been influenced by the periodicity, currency and content of the news from London.

\subsection{Recommendations for further research}

(a) A model constructed using data from a daily published newspaper would provide a more finely-tuned representation of the transmission time. Such a model would have eliminated the enforced time-lag due to the tri-weekly periodicity of the Freeman's Journal. A comparison of the models would show the extent to which periodicity affected the frequency distribution shown above.

(b) The methodology employed in this research could be applied to build models of the currency of news in other contexts:

- London news reported in Dublin newspapers at other periods in the seventeenth and eighteenth centuries;

- Foreign (American and Continental) intelligence reported in Dublin newspapers;

- The difference in currency for Dublin readers between information from newspapers and that of other printed materials (pamphlets, letters, etc) sourced from London;

- London news reported in other Irish port towns;

- The difference in news currency between pre- and post-industrial revolution times.

(c) Explore any correlation between Dublin City newspaper readership fluctuation and the dates given in contemporary Almanacks for specific events occurring on "Remarkable Days". For example, when Parliament was in session, an increased demand for newspapers might be expected. 


\section{References}

Archbold, J. (2008) Irish Periodicals in their Atlantic Context, 1770-1830: The monthly and quarterly magazines of Dublin, with comparison to those of Edinburgh and Philadelphia. Ph.D. thesis, Trinity College, Dublin.

Barnard, T. (2006) Print Culture, 1700-1800. In: Gillespie, R. and Hadfield, A. (eds.) The Oxford History of the Irish Book Volume III: The Irish Book in English, 1550-1800. Oxford: Oxford University Press. 34-58.

Bew, P. (2007) Ireland: The Politics of Enmity 1789-2006. Oxford: Oxford University Press.

Boyce, G., Curran, J. and Wingate P. (eds.) (1978) Newspaper History: from the seventeenth century to the present day. London: Constable.

Carr, J. (1806) The Stranger in Ireland: or, a tour in the southern and western parts of that country in the year 1805. London.

Cox, C. (2000) Women and business in eighteenth-century Dublin: a case study. In: Whelan, B. (ed.) Women and paid work in Ireland, 1500-1930. Dublin: Four Courts Press. 30-43.

Dooley, B. and Baron, S.A. (eds.) (2001) The Politics of Information in Early Modern Europe. London: Routledge.

Dublin Docklands: History and Heritage. URL: http://www.ddda.ie/index.jsp?p=629\&n=113 [accessed 15.1.11].

Gilligan, H.A. (1988) A History of the Port of Dublin. Dublin: Gill and Macmillan.

Hemmeon, J. C. (1912) The History of the British Post Office. Cambridge: Harvard University.

Howe, E. (ed.) (1947) The London compositor: documents relating to wages, working conditions and customs of the London printing trade, 1785-1900.

London: Bibliographical Society.

Inglis, B. (1954) The Freedom of the Press in Ireland 1784-1841. London: Faber and Faber.

Irish Newspaper Archives. URL: http://www.irishnewsarchive.com/ [accessed 31.07.09].

Kinane, V. (2002) A Brief History of Printing and Publishing in Ireland. Dublin: National Print Museum.

Komito, L. (2004) The Information Revolution and Ireland: prospects and challenges. Dublin: University College Dublin Press.

Marmion, A. (1860) The Ancient and Modern History of the Maritime Ports of Ireland. London.

Met Eireann: Our History - The Irish Meteorological Service Online. URL: http://www.met.ie/about/our-history.asp [accessed 12.08.09]. 
Oram, H. (1983) The Newspaper Book: a history of newspapers in Ireland, 16491983. Dublin:MO Books.

Pollard, M. P. (1989) Dublin's Trade in Books 1550-1800: Lyell Lectures, 19861987. Oxford: Clarendon Press.

Reynolds, M. (1983) A History of the Irish Post Office. Dublin: MacDonnell Whyte.

Shee, Sir G. (1797) A Memoir on the Construction of Ships. In: Royal Irish Academy (ed.) The transactions of the Royal Irish Academy, Vol. 6. Dublin, [1787]-1800, edited by Royal Irish Academy. Dublin. 15-25.

Sommerville, C. J. (1996) The News Revolution in England: cultural dynamics of daily information. Oxford: Oxford University Press.

Starr, P. (2005) The Creation of the Media: political origins of modern communications. New York: Basic Books.

Wiles, R. M. (1965) Freshest Advices: early provincial newspapers in England. Columbus: Ohio State University Press.

Williams, K. (1977) The English Newspaper: an illustrated history to 1900. London: Springwood Books.

Willson, B. (1903) The Story of Rapid Transit. New York: Appleton.

Woolf, D. (2001) News, history and the construction of the present in early modern England. In: Dooley, B. and Baron, S.A. (eds.) The Politics of Information in Early Modern Europe. London: Routledge. 80-118.

Wusteman, J. (2008) Virtual Research Environments: What is the librarian's role? Journal of Librarianship and Information Science, 40(2), 67-70.

\section{The Occasion}

Sarah McDonald was awarded a special mention by the judges of the 2010 LIRG student prize competition for her MLIS dissertation: In one forme or another: the currency of London news in Dublin City newspapers, 1790-1801.

\section{Acknowledgement}

Grateful thanks to Dr. Barbara Traxler Brown of University College Dublin for her inspiration, supervision and enthusiastic support.

\section{Open access and copyright}

Library and Information Research is an open access journal. A freely available copy of this paper may be downloaded from the journal's website:

http://www.cilipjournals.org.uk/lir

Copyright and associated moral rights in works published in Library and Information Research are retained by the author(s) but this paper may be used freely, with proper attribution, in educational and other non-commercial settings. 